\title{
Impairment of liver antioxidant defense activity of broiler chickens exposed to benzo[ $\alpha]$ pyrene
}

\author{
I.K. Latif and Ali A.H. Shalash
}

Department of Pathology and poultry diseases, College of Veterinary Medicine, University of Baghdad

Accepted onApril-2011.

\section{Summary}

The antioxidant defense activity system is greatly involved in protecting cells against damage initiated by a variety of endogenous and exogenous compounds. This study was conducted to evaluate the influence of Benzo $[\alpha]$ Pyrene $(\mathrm{B} \alpha \mathrm{P})$ administration on the liver antioxidant defense system. Chicks were assigned into five equal groups, as control, tricaprylin group and three groups treated with $\mathrm{B} \alpha \mathrm{P}(1.5 \mu \mathrm{g}, 150 \mu \mathrm{g}$ or $15 \mathrm{mg} / \mathrm{kg} \mathrm{BW})$. Five birds were sacrificed at days 7, 14, 21 and 35 from each group. To assess the liver antioxidant defense system, glutathione (GSH) concentration, glutathione peroxidase (GSH-Px), superoxide dismutase (SOD) and catalase (CAT) activities were employed. It was found that $15 \mathrm{mg}$ of $\mathrm{B} \alpha \mathrm{P}$ level create significant increase $(\mathrm{P}<0.05)$ in the GSH level, GSH-Px, SOD and CAT activities (18.483, 9.88, 69.44 and 89.88 respectively) of broilers at day 7 postinstillation (p.i.) in compared with control (12.392, 6.51, 41.08 and 50.83). Nevertheless, significant decrease $(\mathrm{P}<0.05)$ in the GSH level, GSH-Px, SOD and CAT activities at 21 and 35 days. A key finding from this study is that exposure to $\mathrm{B} \alpha \mathrm{P}$ may induces oxidative stress on the liver and impair the antioxidant defense system in broilers.

Key words:antioxidant ,broiler, benzo[ $\alpha]$ Pyrene,liver

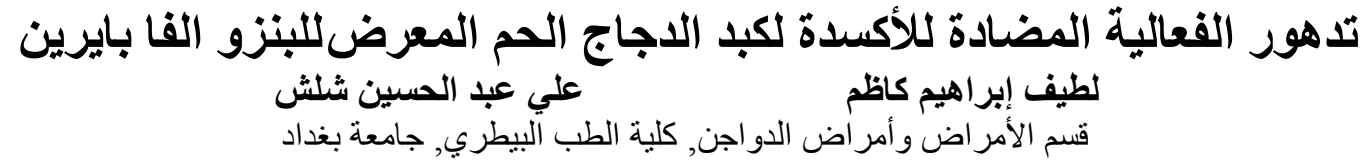

الخلاصة

أن لجهاز المضاد للأكسدة فعالية كبيره للافاع عن الخلايا ضد الضرر الحاصة الحاصل من التأثنير ات الداخلية

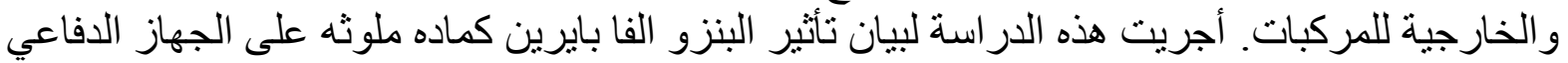

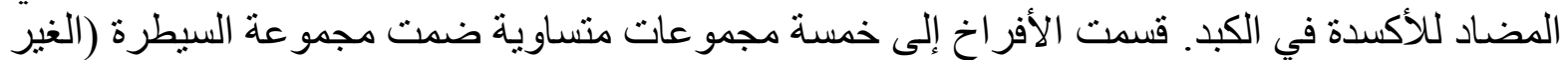

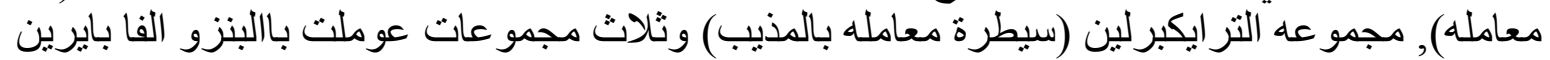

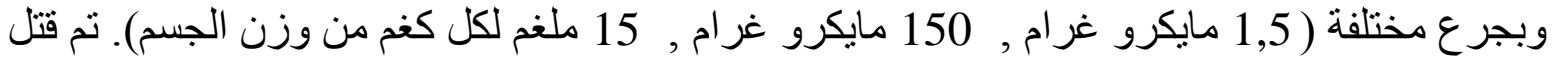

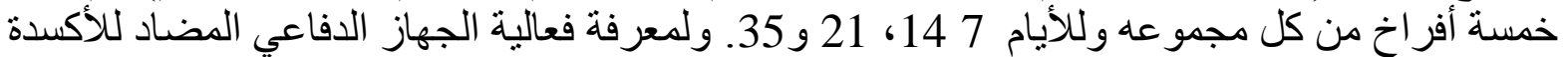

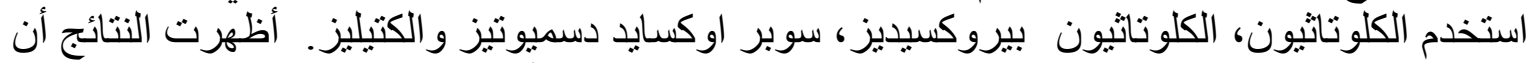

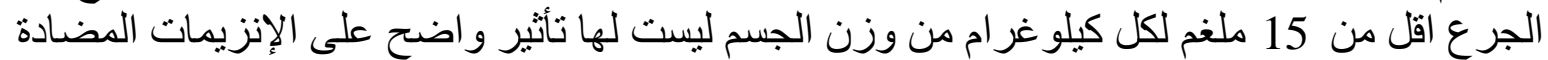

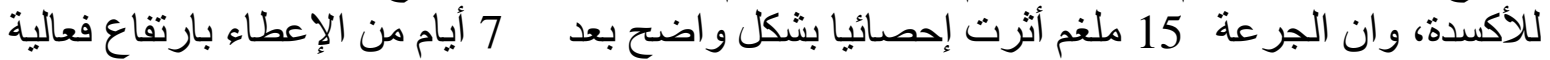

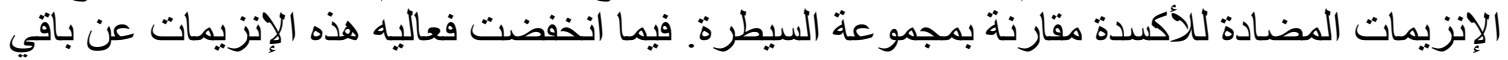

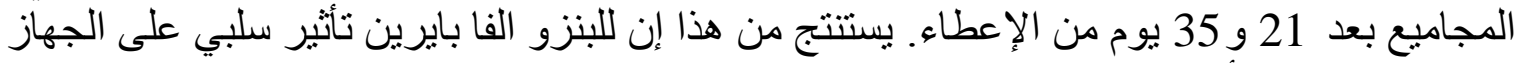

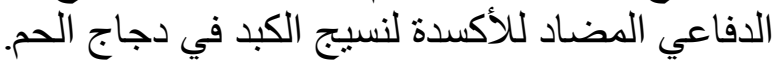




\section{Introduction}

Polycyclic aromatic hydrocarbon (PAH) are a wide spread class of environmental chemical pollutants and known to exert acutely toxic effects as well as to have mutagenic properties. Suppression of the antioxidant defense by $\mathrm{PAH}$, especially $\mathrm{B} \alpha \mathrm{P}$ leads to the generation of reactive oxygen species (ROS) (1). Our previous work documented that $\mathrm{B} \alpha \mathrm{P}$ impair the non-specific respiratory defense mechanism and induce hemato-and hepatotoxicity in broilers $(2,3)$. However, fate and mechanisms of toxic effect of $\mathrm{B} \alpha \mathrm{P}$ on broiler still remain vague.

The body has developed several defense mechanisms against oxidative damage. These defense mechanisms are composed of enzymatic and nonenzymatic systems. Enzymatic defense systems involve certain enzymes such as GSH-Px, SOD and CAT whereas non-enzymatic defense systems involve certain endogenous compounds found in the body include GSH (4). When free radical damage overwhelms compensation of cells, peroxidation occurs, and a series of adverse reactions, including alteration of cell permeability, impairment of intracellular and extracellular transport systems, and intracellular energy metabolisms are observed. Constituting a problem for cells itself, peroxidation is also capable of causing adverse effects on living organisms through intermediate and final products of peroxidation (5). The purposes in this study were to examine the possible mechanisms of the toxic effects (i.g. the inactivation of the antioxidant enzymes) of $\mathrm{B} \alpha \mathrm{P}$. In order to explore the oxidative stress in broilers caused by $\mathrm{B} \alpha \mathrm{P}$, activities of the antioxidant defense such as GSH level, GSH-Px, SOD and CAT activities were also investigated.

\section{Materials and Methods}

Animals and Experimental Design: One hundred -day-old commercial broiler males (Cobb 500) were obtained from a local hatchery. Chicks were assigned into five equal groups, as follows: control (untreated) group, tricaprylin group $(100 \mu \mathrm{l}), \mathrm{B} \alpha \mathrm{P}$ (dissolved in $100 \mu \mathrm{l}$ of tricaprylin) groups $(1.5 \mu \mathrm{g}, 150 \mu \mathrm{g}$, or 15 $\mathrm{mg} / \mathrm{kg}$ of BW, respectively). Chicks within different treatment groups were treated via intra-tracheal instillation (i.t) by using a micropipette for 5 successive days, five birds were sacrificed at days 7, 14, 21 and 35. Chicks were brooded in battery cages with water and a commercial diet were provided for $a d$ libitum intake throughout the study. The diet was formulated to meet or exceed all the minimum national research council (1995) recommendations.

Liver tissue homogenate preparation and protein concentration: Liver was quickly removed after the chickens were killed, the blood being washed out with ice-cold $0.9 \%$ saline solution. For obtaining tissues supernatants, $1 \mathrm{~g}$ of liver tissues were homogenized in $9 \mathrm{ml}$ of $50 \mathrm{mM}$ ice-cold buffer solution $(\mathrm{pH}$ 7.4) containing $1.15 \%$ potassium chloride, using an all-glass homogenizer. After centrifugation at $15,000 \mathrm{rpm}$ for $20 \mathrm{~min}, 4^{\circ} \mathrm{C}$ the resulting supernatant fraction was used to determine the GSH level GSH-Px, SOD and CAT activities. The protein concentration of tissue homogenate was determined using 
bicinchoninic acid protein assay reagents $\left(\mathrm{BCA}^{\mathrm{TM}}\right.$ Protein Assay Kit) with reference to bovine serum albumin acted as the standard.

Measurement of GSH level in liver tissue homogenate: The level of GSH was measured using the method described by Beutler et al. (6). Briefly, $0.2 \mathrm{ml}$ of supernatant was added to $1.8 \mathrm{ml}$ distilled water (DW). Three mls of the precipitating solution (1.67 g metaphosphoric acid, $0.2 \mathrm{~g}$ EDTA and $30 \mathrm{~g} \mathrm{NaCl}$ in $100 \mathrm{ml} \mathrm{DW}$ ) was mixed with this supernatant. The mixture was allowed to stand for $5 \mathrm{~min}$ and then filtered. Two $\mathrm{ml}$ of filtrate was taken and added into another tube, and then $8 \mathrm{ml}$ of the phosphate solution and $1 \mathrm{ml} \mathrm{5,5'-dithiobis} \mathrm{2-}$ nitrobenzoic acid (DTNB) were added. A blank was prepared with $8 \mathrm{ml}$ of phosphate solution, $2 \mathrm{ml}$ diluted precipitating solution, and $1 \mathrm{ml}$ DTNB reagent. A standard solution of the GSH was prepared $(40 \mathrm{mg} / 100 \mathrm{ml})$. The optical density was measured using spectrophotometer (Genesys $10 \mathrm{UV}$, USA) at 412 nm.

Measurement of GSH-Px activity in liver tissue homogenate: The GSH-Px activity was measured by the method of Paglia and Valentine (7). The reaction mixture contained $2.49 \mathrm{ml}$ phosphate buffer (50 mM containing $5 \mathrm{mM}$ EDTA; $\mathrm{pH} 7.0), 0.1 \mathrm{ml}$ NADPH $(8.4 \mathrm{mM}), 0.1 \mathrm{ml} \mathrm{GSH}(150 \mathrm{mM}), 0.01 \mathrm{ml}$ sodium azide $(112.5 \mathrm{mM}), 4.6 \mathrm{U}$ glutathione reductase and $10 \mu \mathrm{l}$ supernatant. The reaction was initiated by adding $0.1 \mathrm{ml}$ of $\mathrm{H}_{2} \mathrm{O}_{2}(2.2 \mathrm{mM})$ to the mixture. The change in absorbance was recorded at $340 \mathrm{~nm}$ at an interval of $30 \mathrm{~s}$ for $3 \mathrm{~min}$. One unit of GSH-Px activity was defined as the amount of enzyme required to 1 mmol of NADPH oxidized/min.

Measurement of SOD activity in liver tissue homogenate: The SOD activity was measured according to the method of Marklund and Marklund (8) based on the ability of SOD to inhibit the autoxidation of pyrogallol. Firstly, $0.5 \mathrm{ml}$ of supernatant was added to $1.5 \mathrm{ml}$ of ice cold DW followed by $0.5 \mathrm{ml}$ ethanol and then $0.3 \mathrm{ml}$ chloroform, mixed well and centrifuged for $10 \mathrm{~min}$ at $3000 \mathrm{rpm}$. Secondly, following an addition of $2 \mathrm{ml}$ of DW, a mixture of reactive solution was prepared by adding $75 \mu \mathrm{l}$ chloroform-ethanol extract (supernatant of the sample) to $2.25 \mathrm{ml}$ Tris- $\mathrm{HCl}(\mathrm{pH} \mathrm{8.0)}$. The mixture was then kept and prewarmed at $25^{\circ} \mathrm{C}$ in a water bath for $10 \mathrm{~min}$, then $0.15 \mathrm{ml}$ of $3 \mathrm{mM}$ pyrogallol solution was added. The rate of spontaneous oxidation was measured in spectrophotometer at $420 \mathrm{~nm}$. Standard controls were measured following the same procedure but the sample was replaced with $20 \%$ ethanol. One unit of SOD activity was defined as the amount of enzyme required to transformation of $1 \mathrm{mmol}$ of the pyrogallol/min.

Measurement of CAT activity in liver tissue homogenate: The CAT activity was measured as described by Aebi (9), phosphate buffer (50 mM, pH 7.0) 1.98 $\mathrm{ml}$ and $20 \mu \mathrm{l}$ of supernatant were mixed in a cuvette. Reaction was started by adding $1 \mathrm{ml} \mathrm{H}_{2} \mathrm{O}_{2}(30 \mathrm{mM})$ and the absorbance was recorded at every $15 \mathrm{~s}$ for 1 min at $240 \mathrm{~nm}$ against a phosphate buffer blank. One unit of CAT activity was defined as the amount of enzyme required to decompose $1 \mathrm{mmol}$ of $\mathrm{H}_{2} \mathrm{O}_{2} / \mathrm{min}$. 
Statistical analysis: The data were analyzed with SPSS 16.0 for Windows by using a two-way analysis of variance (ANOVA). Differences between means were determined using Duncan's tests in which the significance level was designated at $\mathrm{P}<0.05$.

\section{Results}

No significant clinical alterations were observed in any chickens during the course of the experiment. The Changes in GSH levels in liver tissue homogenate of broilers during the experimental period is as shown in Table 1. As time advanced a trend of an increase of GSH values are seen in all groups except that in $15 \mathrm{mg} \mathrm{B} \alpha \mathrm{P}$ group throughout the trial. On the other hand, from day 7 the broilers from the $15 \mathrm{mg} \mathrm{B} \alpha \mathrm{P}$ group has the highest $(\mathrm{P}<0.05)$ and at days 21,35 have the lowest $(\mathrm{P}<0.05)$ GSH values. Such differences were comparable to all other groups at day 14 and to the $150 \mu \mathrm{g}$ of $\mathrm{B} \alpha \mathrm{P}$ group on day 21.

Table (1): Changes in glutathione (GSH) concentration ( $\mathrm{mmol} / \mathrm{mg}$ protein) in liver tissue homogenate (mean $\pm \mathrm{SD}$ ) of broiler males treated with $\mathrm{BaP}$.

\begin{tabular}{|c|c|c|c|c|c|}
\hline \multirow[b]{2}{*}{ Parameter } & \multirow[b]{2}{*}{ Groups } & \multicolumn{3}{|c|}{ Days p. i. ${ }^{1}$} & \multirow[b]{2}{*}{35} \\
\hline & & 7 & 14 & 21 & \\
\hline \multirow{5}{*}{$\begin{array}{l}\text { GSH } \\
\text { mmol/mg } \\
\text { protein }\end{array}$} & Control & $12.392 \pm 0.994^{\mathrm{bB}}$ & $14.695 \pm 1.448^{\mathrm{aAB}}$ & $15.174 \pm 1.813^{\mathrm{aAB}}$ & $16.207 \pm 1.627^{\mathrm{aA}}$ \\
\hline & Tricaprylin & $11.705 \pm 1.130^{\mathrm{bB}}$ & $13.258 \pm 1.752^{\mathrm{aAB}}$ & $14.815 \pm 1.447^{\mathrm{aA}}$ & $15.883 \pm 1.708^{\mathrm{aA}}$ \\
\hline & $1.5 \mu \mathrm{B} \alpha \mathrm{P}^{2}$ & $11.505 \pm 1.643^{\mathrm{bB}}$ & $12.772 \pm 1.500^{\mathrm{aAB}}$ & $13.983 \pm 1.288^{\mathrm{aAB}}$ & $14.982 \pm 1.272^{\mathrm{aA}}$ \\
\hline & $150 \mu \mathrm{g} \mathrm{B \alpha P}$ & $13.183 \pm 1.997^{\mathrm{bA}}$ & $11.906 \pm 1.437^{\mathrm{aA}}$ & $12.274 \pm 1.305^{\mathrm{abA}}$ & $14.620 \pm 1.338^{\mathrm{aA}}$ \\
\hline & $15 \mathrm{mg} \mathrm{B \alpha P}$ & $18.483 \pm 1.379^{\mathrm{aA}}$ & $13.409 \pm 1.371^{\mathrm{aB}}$ & $10.229 \pm 1.121^{\mathrm{bC}}$ & $10.552 \pm 1.248^{b C}$ \\
\hline
\end{tabular}

Although the control, tricaprylin groups showed an increment of liver GSH-Px activity as time advanced, fluctuations were seen in the $1.5 \mu \mathrm{g}, 150 \mu \mathrm{g}$ and $15 \mathrm{mg}$ of $\mathrm{B} \alpha \mathrm{P}$ groups (Table 2). However, at day 7 the $150 \mu \mathrm{g}$ and $15 \mathrm{mg}$ of $\mathrm{B} \alpha \mathrm{P}$ groups were significantly $(\mathrm{P}<0.05)$ increased than any other group. After this, from day 21,35 the $15 \mathrm{mg}$ of $\mathrm{B} \alpha \mathrm{P}$ group has the lowest GSH-Px $(\mathrm{P}<0.05)$ level than any other group. 
Table (2): Changes in glutathione peroxidase (GSH-Px) activity (U/g protein) in liver tissue homogenate (mean \pm SD) of broiler males treated with BaP.

\begin{tabular}{|c|c|c|c|c|c|}
\hline \multirow[b]{2}{*}{ Parameter } & \multirow[b]{2}{*}{ Groups } & \multicolumn{4}{|l|}{ Days p. i. $^{1}$} \\
\hline & & 7 & 14 & 21 & 35 \\
\hline $\begin{array}{l}\text { GSH-Px } \quad \text { U/g } \\
\text { protein }\end{array}$ & $\begin{array}{l}\text { Control } \\
\text { Tricaprylin } \\
1.5 \mu g{\mathrm{~B} \alpha \mathrm{P}^{2}} \\
150 \mu \mathrm{B} \alpha \mathrm{P} \\
15 \mathrm{mg} \mathrm{B \alpha P}\end{array}$ & $\begin{array}{l}6.51 \pm 0.451^{\mathrm{bB}} \\
5.78 \pm 0.722^{\mathrm{bB}} \\
6.02 \pm 0.813^{\mathrm{bB}} \\
7.95 \pm 0.890^{\mathrm{abA}} \\
9.88 \pm 0.694^{\mathrm{aA}}\end{array}$ & $\begin{array}{l}7.31 \pm 0.822^{\mathrm{aAB}} \\
7.42 \pm 0.820^{\mathrm{aA}} \\
7.11 \pm 0.673^{\mathrm{aAB}} \\
7.28 \pm 0.624^{\mathrm{aA}} \\
8.14 \pm 0.721^{\mathrm{aB}}\end{array}$ & $\begin{array}{l}7.56 \pm 0.601^{\mathrm{aAB}} \\
7.49 \pm 0.525^{\mathrm{aA}} \\
6.82 \pm 0.703^{\mathrm{aAB}} \\
6.86 \pm 0.685^{\mathrm{aA}} \\
5.22 \pm 0.582^{\mathrm{bC}}\end{array}$ & $\begin{array}{l}8.85 \pm 0.754^{\mathrm{aA}} \\
8.99 \pm 0.795^{\mathrm{aA}} \\
8.00 \pm 0.677^{\mathrm{aA}} \\
7.29 \pm 0.858^{\mathrm{aA}} \\
6.20 \pm 0.801^{\mathrm{bC}}\end{array}$ \\
\hline
\end{tabular}

${ }^{\mathrm{a}, \mathrm{b}}$ Values bearing similar superscript between column do not differ at $(\mathrm{P}<0.05)$

A, B, C Values bearing similar superscript between row do not differ at $(P<0.05)$

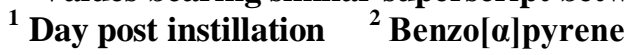

The SOD enzyme activity manifested fluctuations without any clear pattern in all groups during the course of the experiment (Table 3). However, the SOD levels in the control, tricaprylin, $1.5 \mu \mathrm{g}$ and $150 \mu \mathrm{g}$ of $\mathrm{B} \alpha \mathrm{P}$ groups remained unchanged throughout the experimental period and that of the $15 \mathrm{mg}$ of $\mathrm{B} \alpha \mathrm{P}$ group remained significantly $(\mathrm{P}<0.05)$ higher from all other groups at day 7 .

Table (3): Changes in superoxide dismutase (SOD) activity (U/g protein) in liver tissue homogenate (mean $\pm \mathrm{SD}$ ) of broiler males treated with $\mathrm{B \alpha P}$.

\begin{tabular}{|c|c|c|c|c|c|}
\hline \multicolumn{6}{|c|}{ Days p. i. ${ }^{1}$} \\
\hline Parameter & Groups & 7 & 14 & 21 & 35 \\
\hline $\begin{array}{l}\text { SOD U/g } \\
\text { protein }\end{array}$ & 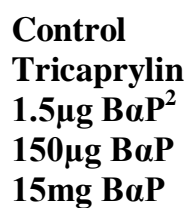 & $\begin{array}{l}41.08 \pm 6.986^{\mathrm{bA}} \\
39.68 \pm 7.573^{\mathrm{bA}} \\
42.70 \pm 6.990^{\mathrm{bA}} \\
45.64 \pm 7.000^{\mathrm{bA}} \\
69.44 \pm 9.109^{\mathrm{aA}}\end{array}$ & $\begin{array}{l}47.97 \pm 5.097^{\mathrm{aA}} \\
48.74 \pm 7.905^{\mathrm{aA}} \\
50.74 \pm 5.684^{\mathrm{aA}} \\
55.85 \pm 8.420^{\mathrm{aA}} \\
58.77 \pm 8.875^{\mathrm{aAB}}\end{array}$ & $\begin{array}{l}55.74 \pm 8.990^{\mathrm{aA}} \\
50.95 \pm 7.755^{\mathrm{aA}} \\
50.70 \pm 9.052^{\mathrm{aA}} \\
55.95 \pm 6.900^{\mathrm{aA}} \\
\mathbf{4 3 . 5 3} \pm 7.795^{\mathrm{aB}}\end{array}$ & $\begin{array}{l}54.90 \pm 8.737^{\mathrm{aA}} \\
53.00 \pm 8.000^{\mathrm{aA}} \\
48.99 \pm 6.933^{\mathrm{aA}} \\
50.64 \pm 7.874^{\mathrm{aA}} \\
46.75 \pm 9.732^{\mathrm{aB}}\end{array}$ \\
\hline
\end{tabular}

${ }^{\mathrm{a}, \mathrm{b}}$ Values bearing similar superscript between column do not differ at $(\mathrm{P}<0.05)$

$\mathrm{A}, \mathrm{B}, \mathrm{C}$ Values bearing similar superscript between row do not differ at $(\mathbf{P}<0.05)$

${ }^{1}$ Day post instillation ${ }^{2}$ Benzo[a]pyrene

There was an ascending increment of CAT activity in all groups except that in $150 \mu \mathrm{g}$ and $15 \mathrm{mg}$ of $\mathrm{BaP}$ groups as time advanced (Table 4). At day 7, the 15 $\mathrm{mg}$ of $\mathrm{B} \alpha \mathrm{P}$ group had the highest $(\mathrm{P}<0.05)$ concentration of CAT than any other group.

Table (4): Changes in catalase (CAT) activity (U/g protein) in liver tissue homogenate (mean \pm SD) of broiler males treated with $\mathrm{B} \alpha \mathrm{P}$.

\begin{tabular}{|c|c|c|c|c|c|}
\hline \multirow[b]{2}{*}{ Parameter } & \multirow[b]{2}{*}{ Groups } & \multicolumn{3}{|c|}{ Days p. i. $^{\top}$} & \multirow[b]{2}{*}{35} \\
\hline & & 7 & 14 & 21 & \\
\hline $\begin{array}{l}\text { CAT U/g } \\
\text { protein }\end{array}$ & 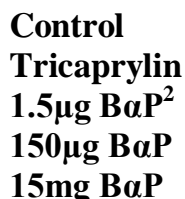 & $\begin{array}{l}50.83 \pm 4.670^{\mathrm{bA}} \\
48.59 \pm 6.979^{\mathrm{bA}} \\
49.04 \pm 7.955^{\mathrm{bA}} \\
55.95 \pm 7.510^{\mathrm{bA}} \\
89.88 \pm 9.904^{\text {aA }}\end{array}$ & $\begin{array}{l}56.97 \pm 7.449^{\mathrm{aA}} \\
58.70 \pm 5.933^{\mathrm{aA}} \\
\mathbf{5 9 . 6 3} \pm 7.900^{\mathrm{aA}} \\
\mathbf{5 4 . 8 4} \pm 6.439^{\mathrm{aA}} \\
67.72 \pm 8.990^{\mathrm{aB}}\end{array}$ & $\begin{array}{l}60.44 \pm 8.680^{\mathrm{aA}} \\
64.66 \pm 9.500^{\mathrm{aA}} \\
61.53 \pm 7.953^{\mathrm{aA}} \\
67.36 \pm 9.944^{\mathrm{aA}} \\
44.41 \pm 7.950^{\mathrm{bC}}\end{array}$ & $\begin{array}{l}64.86 \pm 9.654^{\mathrm{aA}} \\
65.79 \pm 9.066^{\mathrm{aA}} \\
63.77 \pm 7.980^{\mathrm{aA}} \\
62.80 \pm 8.005^{\mathrm{aA}} \\
53.70 \pm 9.080^{\mathrm{aBC}}\end{array}$ \\
\hline
\end{tabular}

${ }^{\mathrm{a}, \mathrm{b}}$ Values bearing similar superscript between column do not differ at $(\mathrm{P}<0.05)$

A, B, C Values bearing similar superscript between row do not differ at $(P<0.05)$

${ }^{1}$ Day post instillation ${ }^{2}$ Benzo[a]pyrene 


\section{Discussion}

The antioxidant system is greatly involved in protecting cells against damage initiated by a variety of endogenous and exogenous compounds. We have previously shown that $\mathrm{B} \alpha \mathrm{P}$ believed to disturb the balance between the production of ROS and the antioxidant systems through markedly increased of MDA levels liver in broiler chickens (2). It should also be noted that oxidative stress has been associated with not only the elevated production of free radicals but also with changes to the scavenging capacity of antioxidant systems. This study represents an assessment of the widely used avian toxicology and biomonitoring antioxidant defense mechanisms (10) of broiler chickens exposed to $\mathrm{B} \alpha \mathrm{P}$. It is strongly believed that the deleterious effects of $\mathrm{B} \alpha \mathrm{P}$ specially in 15 $\mathrm{mg} / \mathrm{kg} \mathrm{BW}$ seen in this study were attributed to redox cycling, which have the potential to produce ROS that overcome the protection afforded by antioxidant defense mechanisms, thereby leading to oxidative damage manifest by damage to the liver tissue macromolecules results in variation of hepatic GSH level, GSH-Px, SOD and CAT activities compared to other groups.

Findings from our study showed that the minimum dose of $\mathrm{B} \alpha \mathrm{P}$ to elicit toxic effect in poultry is $15 \mathrm{mg} / \mathrm{kg}$ i.t, the existence of specialized lung and air sacs (11) has rendered avian to be less affected by $\mathrm{B} \alpha \mathrm{P}$ at low levels. We believed that much of the $\mathrm{B} \alpha \mathrm{P}$ at low doses was localized in the poorly vascularized air sacs and may be entrapped by heterophils and macrophages (12). Although at higher doses, such scavenging systems might have been saturated, leading to an active biologically available $\mathrm{B} \alpha \mathrm{P}$ to elicit toxicity. The cytotoxic effect of $15 \mathrm{mg}$ of $\mathrm{B} \alpha \mathrm{P}$ involved increasing of GSH level, GSH-Px, SOD and CAT activities at 7 days p.i. and decreasing at 21, 35 days (Tables 14). This response is indicative of cellular oxidative stress apparently causes the induction of the activity of this enzyme that takes part in toxic compound removal.

Conclusions : the present data show that $\mathrm{B} \alpha \mathrm{P}$ could enhance the activity of GSH level, GSH-Px, SOD and CAT activities at 7 days and decreases the antioxidant capacity at 21,35 days. These findings indicated that $\mathrm{B} \alpha \mathrm{P}$ induce oxidative damage to liver tissue, this may probably be due to an increase in metabolic oxidation capacity or due to failure of a self-propagating scavenging system.

\section{References}

1. Briede J Godschalk R Emans M De Kok T Van Agen E Van Maanen J Van Schooten F and Kleinjans J (2004), In vitro and in vivo studies on oxygen free radical and DNA adduct formation in rat lung and liver during benzo[ $\alpha]$ pyrene metabolism. Free Radic Res. 38: 995-902.

2. Latif IK Karim AJ Zuki AB Zamri-Saad M Niu JP and Noordin MM (2010), Pulmonary modulation of benzo[ $\alpha]$ pyrene-induced hemato-and hepatotoxicity in broilers. Poult Sci. 89: 1379-1388. 
3. Latif IK, Karim AJ, Zuki AB, Zamri-Saad M, Niu JP and Noordin MM (2009). Respiratory macrophage activity and pulmonary morphology following exposure to benzo[ $\alpha]$ pyrene in broilers. Online J Vet Res. 13: 128-135.

4. Halliwell B (1999). Antioxidant defense mechanisms: from the beginning to the end (of the beginning). Free Radic Res. 31: 261-272.

5. Comporti M. (1993). Lipid peroxidation, biophatological significance. Mol Aspec Med. 14: 199-207.

6. Beutler E Duron O and Kelly M (1963). Improved method for the determination of blood glutathione. J Lab Clin Med. 61: 882-885.

7. Paglia DE and Valentine WN (1967). Studies on the quantitative and qualitative characterization of erythrocyte glutathione peroxidase. J Lab Clin Med. 70: 158-69.

8. Marklund S and Marklund G (1974). Involment of the superoxide anion radical in the autooxidation of pyrogallol and a convenient assay for superoxide dismutase. Eur J Biochem. 47: 469-474.

9. Aebi H (1984). Catalase in vitro. Methods Enzymol. 105: 121-126.

10. Lin H, Decuypere E and Buyse J (2006). Acute heat stress induces oxidative stress in broiler chickens. Comp Biochem Physiol. 144: 11-17.

11. Corbanie EA Matthijs MG van Eck JH Remon JP Landman WJ and Vervaet C (2006). Deposition of differently sized airborne microspheres in the respiratory tract of chickens. Avian Pathol. 35: 475-485.

12. Crespo R Yamashiro S and Hunter D (1998). Development of the thoracic air sacs of turkeys with age and rearing conditions. Avian Dis. 42: 35-44. 